\title{
RESEARCH, IDENTIFICATION AND MONITORING OF THE NEEDS OF OCCUPATIONAL TRAINING OF SOCIAL ACTIVITIES EXPERTS
}

\author{
Venelin Terziev ${ }^{1}$ and Nikolay Nichev ${ }^{2}$ \\ ${ }^{1}$ Professor, Ph.D., D.Sc. (National Security), D.Sc. (Ec.), University of Rousse, Rousse, Bulgaria; \\ National Military University, Veliko Tarnovo, Bulgaria; University of Telecommunications and Post, \\ Sofia, Bulgaria, terziev@skmat.com \\ ${ }^{2}$ Colonel Associate Professor, Ph.D., National Military University, Veliko Tarnovo, Bulgaria, \\ nicheff@gmail.com
}

\begin{abstract}
This paper reviews and analyzes the stages of development of social worker's occupation as describes in details all stages of development of this process in Bulgaria. Described and analyzed are the main connections of this process as well as the cooperation of all participants in this stage as well as the end user. Presented is profile of the social worker as made is critical attempt for identification of main needs of occupational training of social activity experts. Based on this critical analysis drawn are several complexes of recommendations and proposals.
\end{abstract}

Keywords: social worker, occupational training, social activities.

\section{INTRODUCTION}

The research interest to the occupation ${ }^{*}$ of the social worker manifests from the insufficiently clear profile in Bulgaria at the moment, according to the dynamic needs of population. Mainly discussed are issues related to what professionals in essence the social activity experts are, what their rights, duties, responsibilities are, which are the areas of realization, what the models of occupational activity are which shall be performed according to the example of other countries where the occupation of the social worker has traditions and accumulated good practices.

"As „occupation" understood is a combination of knowledge and skills, necessary for the execution of certain position, acquired through training or work experience - National Classification of Occupations and Professions, 2011. 


\section{ESSENCE OF THE SOCIAL WORKER'S OCCUPATION IN THE CONTEXT OF RENDERED SOCIAL SERVICES}

In July 2014 in Melbourne the Executive Committee of International Federation of Social Workers (IFSW) and International Association of Schools of Social Work (IASSW) reach consent that the review of the social worker's global definition has ended and suggest presented to be new definition for the occupation of the „social work", namely: "Social work is occupation, based on the practice and academic discipline promoting social change and development, social cohesion and the empowerment and liberation of people. The principles of social justice, human rights, collective responsibility and respect to the differences are central for the social work. Based on the theories of social work, social science, humanitarian studies and knowledge of the native population, social work engages people and structures for dealing with the challenges of life and improvement of wellbeing. The aforementioned definition may be extended at national and/or regional level"."

According to the recent editing of the Social Assistance Act (amended and completed Official Gazette issue No 8 dated 29 January 2016) in Bulgaria the social work is defined as follows: "Social work" is occupational activity for improvement of mutual adaptation of people, families, groups and environment they live in. It is a complex of supporting activities, directed towards achieving better quality of life, dignity and responsibility in people on the grounds of their individual abilities, inter-personal relations and resources of community".

Social work is practice, occupation and academic discipline which recognizes that the interrelated historical, social and economic, cultural, territorial, political and physical factors serve as opportunities and/or obstacles for the welfare of the human and his development. The structural barriers contribute to the perpetuation of inequality, discrimination, exploitation and oppression. The development of critical consciousness by reflecting the structural sources of oppression and / or privilege based on criteria such as race, class, language, religion, gender, culture and sexual orientation, as well as developing strategies for action towards solving structural and personal barriers are central to emancipatory practice when goals are empowerment and liberation of people. In solidarity with those who are disadvantaged, the profession of social work seeks to reduce poverty, liberate the vulnerable and oppressed and promote social inclusion and social cohesion. The social change mandate is based on the premise that the intervention in social work is realized when the current situation at the level of the person, family, small group, community or society, is defined as requiring change and development. It is activated by the need to challenge and change the structural conditions that contribute to marginalization, social exclusion and oppression. Social change initiatives recognize the place of human activity for achieving progress in human rights and economic, ecological and social justice. The profession is equally engaged with maintenance of social stability while it is not used to marginalize, exempt or oppress any specific group of people. Social development conceptualizes as such through which marked are the intervention strategies, desired end conditions and political framework as the latter is completed by the institutionalized frames. Social work is based on overall biopsychosocial, spiritual estimates and interventions that will pass to micro-macro division, include various levels of the system and sector and interprofessional cooperation, directed towards sustainable development. Is gives priority to social-structural and economic development and is not subscribed to conventional wisdom that the economic growth is precondition for social development.

Many structures and taxonomies have been established in order to assist the workers to get oriented in the social work theories. In its fundament many of the classifications reach to human nature discussions, the relative significance of biological, culture and experience in human development and social movements, defining and forming the human society (T.1986). One of the greatest divisions in social work theory creates two large academic disciplines - psychology and sociology through the prism of inter-structural and psychological explanations of personal issues. With the structural perspectives the focus is on political, economic and material environment where people are - poverty and inequality, social injustice and the socalled „bad social functioning”. In the practice most social work theories are strongly affected by the psychological perspective towards human behavior - the ways we develop, study and react. Attention is paid to the emotional side of people's lives and quality of their relations with children, parents and partners. Understanding, support, meeting emotional needs, control on experiences are accepted as approach to settling the problem. This approach includes several stages, presented in details in figure 1, namely:

- identification, description and measurement of the problem;

- analysis of factors, including behavior of other people creating the problem;

- selecting objectives to solve the problem;

*http://ifsw.org/policies/guiding-principles-for-social-workers-working-with-others-to-identify-and-protect/ 
- determining and performing those actions through which reached will be the objectives and solved will be the problems.

\section{PROFILE OF THE SOCIAL WORKER RENDERING SOCIAL SERVICES}

Identification of social worker's professional profile rendering various social services in Europe is complex having in mind that the European Union countries name in various ways experts, engaged with social work. In the American and European literature sources attempts are made concluding the general occupational characteristics of the social worker (2002a-c,2003a-e,T.2004).

Most generally at descriptive level, the social worker's occupational profile includes three components:

- professional skills;

- professional roles;

- professional competences.

Professional skills. In their foundation are the characteristic for the occupation practical activities which the social worker carries out with the purpose of supporting people and families to recover their abilities and take part in the social life. Those activities may be conditionally distributed in two categories - actions with "direct” and ,indirect" impact.

Direct impact activities are often undertaken with the purpose of easing and solving certain social problem for a specific client (individual, family). This is social work with client and others in his favor. Those activities include individual estimate of the client's status, consulting or rendering specific service, intermediation with other services and institutions. Estimate of the client is a complex process and includes a selection of activities as orientation in his problems, gathering impressions regarding the environment he lives in, discussion of his problems with the remaining members of the team in the respective social service, reaching agreement with him. Consulting includes conversations that the social worker conducts with the client and which aim to change his attitude, understanding towards some aspects of life or relations with other people and groups as taking into consideration the psycho-social condition of the client. Intermediation helps the client create contracts with various agencies and services with the purpose of receiving assistance and what he needs.

Indirect impact activities affect general tasks of social problems' prevention with the purpose of improving social services. With them the focus are other social services, agencies, institutions and building connections between them, management, supervision and training of their personnel.

In $90^{\text {s }}$ of XX century at the College of Social Works at the University of South Carolina, USA ${ }^{*}$ held is scientific research of social workers' activity, analyzing the work place of the social worker. The aim of the study is to establish the main activities, performed by the social worker. At representative principle interviewed were social workers holding various positions in the public as well as private sector. Study's results indicate the following main groups of activities:

- individual work with clients;

- work on separate case;

- informal training of clients with the purpose of building skills for dealing with household and everyday life;

- providing the client with the necessary resources (contact with employers, experts - psychologists, pedagogues, legal advisers, physicians and so on);

- estimate of resources, necessary for the client;

- compiling plan for work with the client;

- compiling risk assessment;

- organizing specific services to the client;

- work in groups;

- monitoring of social worker's quality of work;

- personnel management;

*http://www.cosw.sc.edu/, The College of Social Work at the University of South Carolina 
- planning, organizing and work on programs (new services);

Analysis indicate that social workers, regardless whether engaged directly with work with clients or hold managerial positions take part in self-development activities - acquiring skills, knowledge and values, necessary for improvement of professional activity (reading professional literature, participation in seminars, work information exchange).

Professional roles. The notion role in social studies is borrowed by the theater. Social and psychological significance of the notion is connected to "preliminarily prescribed behavior of certain person in the environment of cooperating individuals with regards to specific activity". The occupation of the social worker characterizes with significant number of professional roles which according to some researchers are more than 40. Enrichment and dynamics of the role update the personal and professional profile of social worker, they reflect the changes in work situation. Every social worker practices certain number of roles which comply with his personal and professional philosophy, competence, character and work conditions. According to M. Mihaylov when roles are performed, they shall be "played" from the position of the most successful scenario with regards to social point of view and the estimate of personal capabilities and attitudes is inevitable. Most generally, according to western models of social work the social worker is expected to play the following professional roles: assistant, analyst, consultant, informer, mediator, advocate, mentor, animator, expert, researcher, coordinator, mediator, teacher, cooperative assistant, associate, friend, opponent, innovator, competitor, authority, facilitator, executer.

The variety of professional roles is sequence of the difference in theoretic preparation and occupational experience and practice of the social worker as well as his formal and informal education.

Professional competences. Regardless that the term competence is used in the papers of several authors prior to this (French sociologists 1950, Mishel, 1968 and others), all researches recognize that the article of David McClelland („Testing for competency rather than intelligence”. American Psychologist, 28, 1973) is the one truly popularizing the notion skill - competence. McClelland claims that the term competence shall replace the term "skill" which is too clear. According to him, standard work analysis methods, focusing on minimal skills miss things, for example how exceptional people work, what is the difference between mediocre and successful workers. With accepting the Lisboan strategy (2010) a decision was made for modernization and increase of quality of education which to lead to mastering seven universal key competences: mother tongue communication; foreign languages communication; mathematical competence and basic knowledge in the field of natural studies and technologies; digital competence; study skills; public and civil competences; initiative and entrepreneurship. With accepting the National Qualification Framework in Bulgaria legitimized where four universal personal and professional competences, as results of training: independence and responsibility; learning competences; communication and social competences, professional competences.

Competences, specific for the social worker are:

- communicating with people and organizations, creating work relations, engagements;

- cooperating and facilitating people to use their strong features and experience through providing information, advice and so on;

- estimating the situation together with the client and planning activities for overcoming the needs and risk;

- contributing with his work for the development and progress of respective organization as gets included in its activity;

- teamwork skills'

- managing and estimating his own perfection capacity.

\section{PROFILE OF THE SOCIAL WORKER RENDERING SOCIAL SERVICES IN BULGARIA AND SECURING THE SOCIAL ASSISTANCE SYSTEM WITH SOCIAL ACTIVITIES EXPERTS (2002A-C,2003A-E,T.2004,2012A-B,2014A-D,2015A-D,2016A-B)}

Social work within our country is not closed for "foreign impacts”. It is affected by universalized and unified tendencies of globalization. International organizations, related to professional community of social workers and social work schools are very attractive in professional exchange. Their contribution is the adoption of international definition of social work (2014) as well as initiative for fabricating and establishing work qualification standards. They are subject of work conference of International Federation of Social Workers in Adelaide (2004). 
In the eastern European countries introduced are European-American theories and applied methods of social work. With this established are conditions for renewing the bureaucratized state social assistance systems. At the same time performed is cultural and professional exchange which places the practice in those countries on new grounds. Through the financial and methodic assistance received according to various projects and programs the countries of Eastern Europe modernize their systems by adopting western models in social assistance.

European Union promotes the efforts of those countries as suggests mechanisms for institutional construction of their administrations. Funds the internal reforms by giving them possibility to create certain or transform already existing structures which to obtain support through access to practices - experts with experience in the respective field. This way, for example, in the beginning of 2002 signed is agreement between Bulgaria and Austria for institutional construction of Child Protection State Agency and municipals child protection divisions.

In the last 10 years in Bulgaria working are experts from the USA, Great Britain, Scotland, France, Denmark, Austria, and Germany. Undoubtedly the pluralism of ideas is useful but also confusing in cases when there is no clear view of what shall be achieved. The suggested social work models require careful analysis by taking into consideration the differences in societies with regards to ethnic cultural traditions and life philosophy. Models suggest different than our social, economic and institutional conditions. They can be hardly used without material modification and adaptation to the Bulgarian environment, observing the traditions, experience and training of social workers.

The aforementioned underlines the topicality of the question: What expert/ professional the social worker in Bulgaria is? What are his needs of continuous professional training with the purpose of increasing the quality and efficiency of social work as a whole?

Outlining the professional profile of the social worker in Bulgaria is a research problem with two possible approaches. They are preconditioned on the specific peculiarities of the country. They report the fact that social work exists in Bulgaria recently and this is why, even though to a different extend, seek specific cross points between the practices and existing theoretic settings. Inevitably in both approaches reference is made to the practice of countries with a history in social work. The first approach is the way of analogy with countries where social work has a long tradition. As a result of research and analysis of their practice is synthesized profile - model, and the profile of Bulgarian social worker seems to be based on "deviations" from ideal. The second approach focuses on accepted national views on the nature and content of social work and general profession values (confidentiality, non-discrimination, solidarity, legality, loyalty to the organization, colleagues, customers, society, profession and so on..). On this basis set is a profile - a model in which professionally significant features of the social worker are a function of social practice in Bulgaria.

The first approach is maintained by Merdzhanova and Gospodinov (Y.2003), in their research on professional peculiarities of social workers here. They synthesize a descriptive model based on psychological estimates of several occupations that are modern in Bulgaria during recent years and western researches on work of social workers. The model described the social worker with:

- professional roles: consultant, intermediary for obtaining social services, advocate, intermediary for obtaining social assistance, activist, communication intermediary, proxy, teacher, imitator, coordinator, researcher, organizer of work with groups, public spokesman (Z.1999a).

- professional competences: direct intervention when working with individual clients, current management of specific case for a specific client, forming adaptive skills for the everyday life, connection of the client with the necessary resources and active intermediation in client's interests, adopting a plan for services, estimating the needs of services with group, observation on the quality of work, personnel management, work with documentation, current administration, management of organizational changes, planning, preparation and estimate of programs (M.1999).

- main groups of professional abilities: scientific and scientific and applicable, diagnostic, methodic, communication, information, management, work with documentation.

Based on the model held is a research where part will take 72 social workers from Sofia and Panagyurishte, working at Social Assistance Municipal Service. Data indicate that the professional competences of the social worker in Bulgaria are mostly related to rendering social and legal consultations (76\%), distribution and rendering social assistance $(71 \%)$, contacts with other institutions and media (49\%), directing elderly to other social authorities (36\%). The leading professional roles are: direct contact with clients $(71 \%)$, work with documentation $(76 \%)$, contacts with other institutions $(51 \%)$ as with lowest relative share are the direction for development of individual training programs, intervention programs, programs for utilization and applying new techniques in social work. Barely $29 \%$ of the questioned indicate that they consider very important the 
maintaining and increasing of professional awareness and qualification. Authors outline a profile of the social worker which characterizes with:

- professional roles: consulting, intermediary, coordination, management

- professional activities: direct contacts with clients, contacts with other institutions, social assistance

- deficits in professional training: consulting and supporting of clients with specific and special needs, selfdevelopment and information exchange, development and applying new programs and approaches.

The second approach is adopted in this paper. Attempting to construct the professional profile of the social worker here established is a descriptive model reporting national views of social work as well as set in various normative documents, government strategies and programs. They determine the framework where developed is social work in Bulgaria. The analysis suggests strive to adequately combine the available national resources with the EU requirements. Adopted is the thesis that within the European social model every country looks for the most appropriate solutions which comply with the specifics of the economic, financial, social and demographic conditions and perspectives as fundamental ideas, principles and targets are similar.

The selected approach to the research problem allows underlining the common in the professional social activity, based on values valid for everyone practicing it and related to the designation of social work (to defend the weakest society members and support all citizens to maintain an independent way of life) and its professional philosophy (,care for the potential growth of every personality; respect to all personality, faith in dignity and value of every individual; empowering the weak and marginalized" (D.2003)) as at the same time outlines the specific in the model of social work while reporting the social, economic and institutional conditions where it is practiced.

The approach takes into consideration that the development of social work in Bulgaria is affected by the connections and interactions between processes of indemnifications, institutionalization, internalization and unification, generated by social-economic transformations in society and our membership in the European Union.

The design of professional social activity in Bulgaria is the fruit of economic and political considerations which effect on it is in direction of reasonable sufficiency, maximal efficiency, transparency, accessibility and reporting. It is accepted is a tool of social change which contributes to the social cohesion, social solidary and control over inequalities with review of optimizing the social relations and active maintenance of social balance.

According to the Social Assistance Act (Official Gazette, issue 120/200) social workers immediately realize the social assistance tasks. They provide services based on individual approach and assessment of specific needs of people and families. They aim to improve the mutual adaptation of people and the environment they live in order to reach better quality of life, dignity and responsibility based on individual abilities, interpersonal relations and resources of community such as:

- satisfy the main vital needs that the person cannot do for himself;

- strengthen and develop the social solidarity in hard everyday situations;

- assist the social re-integration and employment;

- promote the development of alternative social services.

The realization in full of the stated tasks imposes to social workers also professional roles

1. work with the client in order to estimate his needs. Social workers are at the entrance of the social assistance system. They determine the access according to the established criteria. They are required to have the necessary competence with regards to information they collect as well as to contact they make.

2. work with the client in order to overcome specific hindering situation (the so-called case work). Social workers implement activities with regards to specific client and vulnerable groups in society. They are engaged in rendering assistance and services. They develop individual plans, realize them and estimate the results of the basis of work relations with the client and teamwork. They plan, organize and control their own work and the work of others with the purpose of reaching set goals; dedication to work and abilities to work under pressure.

3. risk management. Social workers encounter serious problems with people causing troubles. Necessary is to recognize the risk for themselves, for the client and others and they shall be able to avoid and minimize it. This is related to determining, estimating and analyzing risk; balancing the rights and responsibilities 
related to risk; undertaking specific actions, risk monitoring; observing the safety procedures.

4. professional development. Social workers shall show responsibility towards their professional training, criticism towards their actions and increase their professional qualification with review the changes in social assistance policy. Introduction of new services and requirements towards their activity imposes constant perfecting and continuous training. Strive to success and willingness to develop their potential.

5. work at organization. The social worker is member of the employment team / group. Works with colleagues in a team, observes the employment discipline, maintains work documentation in appearance confirmed by the organization. Works according to the organization's policy.

6. support of the client. Social workers, on behalf and in favor of the client, defend his rights and express their needs and opinion, cooperate with the clients to organize and set their demands.

The so-defined professional roles position social workers as oppose to clients, own institution, other experts and institutions, engaged in implementing social policy, respective social assistance policy. The first two groups regard direct work with the client, the second two are related to risks in occupation and professional development and assure effective implementation of groups 1 and 2 as well as groups 5 and 6 . This way they form a core of activities above which constructed are the latter two, related to functional roles regard to the work of the social worker as employer of organization on one hand and at the same time representative of clients on the other. Upon realization of professional roles and competences the social worker steps on professional ethics and values. Their execution requires of the social worker analyticity, emotional intelligence, empathy, social literacy, constant maintenance of knowledge, high civil, social and political responsibility.

The following conclusions may be drawn:

1. Missing are profound researches on the occupation of social work, professional profile and qualification of social worker in Bulgaria as well as the necessity of constant maintaining continuous training. In this sense the presented research, described in details in chapter third, point 3.2 are first attempts.

2. Throughout recent years professionally significant characteristics of Bulgarian social worker dynamically change with review of the accelerated bringing of social legislation in compliance with the once of the EU member-states. The social worker profile is outlines in the process as sought are cross points between the practice here and the EU member-states.

In the Bulgarian conditions professional competences of social worker are in three directions - direct work with clients, work in organization, work with colleagues, other experts and institutions. At the front are the priority functions - consulting, intermediary, coordination and management. Priority access to social assistance and services, maintenance and increase of professional awareness and qualification, observing the state institutional policy and priorities, teamwork.

The aforementioned allows making a statement that social workers here are engaged with social work, expressed in providing social assistance, social services and activities of social integration and defense of people and families. Their professionally significant characteristics are in compliance with the degree of institutionalization of occupation social worker in Bulgaria and extending the professional area.

In this context logically comes the question: What the degree of professionalization of social worker's labor in Bulgaria is?

As Pavalko (P.1971) states occupations have characteristic features:

-presence of system of abstract scientific knowledge, necessary for the practice of the respective occupation.

- special continuous training which is mainly obtained in the higher institutes, then during work.

- professional competence which is after acquiring the respective education, through the system of licensing and may be revoked under certain conditions.

- high degree of internal specialization. Within certain occupation formed are fields of occupational activity which are relatively individual.

- high degree of autonomy when working. Work of a professional may be estimated and controlled only by another professional.

- ethical professional code.

- professional associations, different than trade unions. 
- feeling of belonging to the professional community.

- specific method of building relations with the client as accepted is the fact that the professional knows better what the client needs from himself.

Comments following after the aforementioned:

- The system of scientific knowledge, necessary for the practice of social work in Bulgaria starts to erect. To the social work field directed are experts of similar scientific majors (psychologists, pedagogues, sociologists, medical workers etc.) This is natural for social work has inter-disciplinary character. They set the beginning of social work as scientific field and in recent years they are joined by trained social activities experts. Effort is put into accepting a unified terminology and forming a basic structural core of knowledge, forming the outlook of social work as a science. Still there are issues when structuring the scientific base of social work and the tendency of introducing theoretic models of other sciences is not yet overcome where experts identify themselves with the major they come from, and social work is presented as pedagogy, presented as applied psychology etc.

- Until the mid- $90^{\mathrm{s}}$ Bulgaria has no special training of social work personnel. With social work engaged are experts who do not have the necessary education and perform activities which require higher qualifications. This is reflected on the efficiency of work. Present is necessity of new type of experts. Missing is connection between higher schools which train social activity experts in normal communication between the members of scientific community. Attempt for integration of teachers is the creation of „Social Activities Teachers in Bulgaria Association" (1997). Unfortunately this structure is dysfunctional until today. During recent years endeavors are made to activate contacts between experts through organization of and participation in social work scientific conferences.

- Established is Bulgarian Social Workers Association. The initiative for its establishment comes from the teachers and not those, employed in the social field. Members of the association are very few of the social workers. At the moment member are mostly social workers, employed in the non-government sector. The association has developed "Ethical Code of the Social Worker" but it is not accepted by Ministry of Labor and Social Policy and is not mandatory for the social workers in the country. The professional organization needs organizational and financial support.

- At the moment part of the social workers in Bulgaria have no special training in social work and this status quo is impossible to change in near future. The issue of licensing the social workers remains open. Every university diploma in social activities is considered sufficient to provide a license for the social work. Higher institutes are independent in validating the qualification they offer. The Bulgarian Social Workers Association is weak to perform actual regulation of the social work occupation - registration of social workers, expectations of constant professional growth, professional status, criteria for good professional practice, ethical code. The Ministry of Labor and Social Policy attempts to develop professional standards. An impression is made of dis-coordination /inconsistency between education and practice/.

The aforementioned allows stating that "social work" as young occupation in the Bulgarian professional life has difficulties to be legitimized and be assured with educational and practical experts. There is a hazard of blurring the professional appearance. Necessary is adequate development of its contents as determined is its place in the up-to-date hierarchy of professions, professional profile of the expert, qualification characteristics for all academic and qualification degrees and job descriptions for the work places.

A conclusion may be drawn that despite the difficulties in Bulgaria a social worker profile starts to form, in many ways similar to the one in the western European countries. It complies with the changes in the social assistance system caused on one hand by recommendations and requirements of the European Union and World Bank and on the other - of the dynamically changing needs of the population.

The assuring of the social assistance system with social activities experts is an issue which 14 years after passing of the Social Assistance Act (2002) continues to be up-to-date. Throughout the years social work in Bulgaria has always been understood s care, giving social benefits and training (E.2010). The social worker is expected to mostly estimate, with the purpose of assuring financial assistance or other kind of material support that the client is entitled to. The change of those public views will require time. The beginning is set with adopting the Social Assistance Act (2002) which gives legislative interpretation of its content and legitimizes it as a new practice in the social assistance system in Bulgaria.

The first school for social workers was established in Sofia in 1932. In the end of the $50^{\mathrm{s}}$ of XX century PMI starts to teach semi-higher medical personnel - social workers for the system of public health and social care. Part of them work to public councils in the field of social care. Practically to the changes of the beginning of the $90^{s}$ social workers in the structures of social care have semi-higher medical education or 
higher economic education in major „Social Activity”.

In 1990 in the social care system (SCS) employed are 18000 people (Lyubomir.1993). The analysis of the qualification level indicates very low academic level: higher education- only $4.57 \%$, semi-higher- $11.04 \%$, secondary special $-11.89 \%$, secondary- $15.02 \%$, and primary and lower- $57.48 \%$ (E.2010). In 1991 held are competitions for directors of РЦСГ. Increased are the requirements for starting work at the SCS. The relative share of higher students reaches $10 \%$ but they have too various majors. Despite, in mid- $-90^{\mathrm{s}}$ there are still no requirements to the major of the newly-assigned in the system (E.1996). Practically there is no special training of personnel for social work. In the field of social activities formed is a need of new type of experts with complex training, able to render systematic, purposeful and qualified professional assistance to people and families being to a different extend in social and health risk. This type of experts find legitimation with forming the professional field of "Social activities” at the National Classification of Occupations, confirmed by Order No 54/26.03.1996 by Ministry of Labor and Social Policy. The experts in it are distributed in 3 categories: managerial officials at the Social Care Centers and Social Institutions funded by the budget (code as per National Classification of Occupations- 1155); analytical experts in social activities (code as per National Classification of Occupations- 2445); applied social activity experts (code as per National Classification of Occupations - 3461).

In 1999 the Ministry of Labor and Social Policy (Order No5/16.02.1999) confirms normative for service and number of personnel in the social assistance system, classifier of occupations and ways of basic monthly salaries, qualification requirements for holding position and type of job descriptions. For the first time since the beginning of the transition the state, presented by the Ministry of Labor and Social Policy claims what types of experts it needs in the social assistance system.

According to the types of job descriptions, social workers (code as per National Classification of Occupations -2445) perform basic employment tasks and obligations, related directly to the work with clients:

- researching, study, processing and systematizing information about the client;

- organizing and implementing social assistance (social assistance or social service, including rules about their type and size);

- keeping personal files for the individuals being supported;

- periodic inspections for the individual and families being supported with review of maintaining the topicality of the support;

- individual work with clients for social adaptation and integration;

- consulting the client about issues important for him, including in the field of social support;

- directing the client to other experts, services and institutions, if necessary.

The social worker also has obligations which indirectly affect his work with a certain client. They regard his participation in the programs being developed for various groups of clients; the maintenance of connections with state and local authorities and organizations having regards to social assistance (assistance and services) or to problems of the respective group of clients. For holding the position "social worker" set are requirements for education - higher, semi-higher or secondary special and major: social activities, social pedagogy, social worker.

As sequence, Order No5/16.02.1999 of the Ministry of Labor and Social Policy, is revoked. Modified are the titles of positions as for example the title "social activities expert” replaces „social worker”. In 2003 the Ministry of Labor and Social Policy (Social Assistance Agency) starts a procedure for development, update and confirming the job descriptions in the Agency. The changes in the job descriptions are imposed due to changes in the character of the activity and work organization. New types of job descriptions are effective as of August 2003. There unambiguously stated is that social activities experts perform social work expressed in providing social benefits, social services and activities for social integration of people and families in need as well as activities of child protection, in accordance with the effective legislation. Determined are fields of activity:

- granting social benefits and rendering social services;

- social integration and rehabilitation of disabled people;

- child protection (family support, prevention, re-integration, adoption, foster care);

- accepting and processing application, complaints, alerts; 
- partnership with other institutions, organizations, citizens and civil associations, companies on issues, related to social protection and vulnerable social groups;

- research of the needs of social assistance and services of people and families on the territory of the municipality, in compliance with the normative regulations.

The division of posts ,junior” and "senior” expert is formally as per degree without grading of duties and responsibilities according to the level of complexity. Holding them requires professional experience in humanitarian, social, economic and legal sciences. There are differences in the required skills and competencies in both expert positions. As leading stated are the skills: teamwork, knowledge of the principles and methods of social work, applying individual approach, planning, knowledge of regulations, estimation of needs, striving for self-improvement and professional development, computer literacy. Competences of the social activities experts are related to knowledge of laws and regulations, serving social field, knowledge of the internal functioning of Social Assistance Agency and Ministry of Labor and Social Policy, knowledge of the demographic structure of the region, social status of population, groups at risk and priority of their needs, social services within the community.

As of May 2004 the titles are again modified as ,junior social activities expert” and „senior social activities expert" are renamed to "social worker" and as of November of the same year revoked is the requirement for education. The applicants for the „social worker” position are required to only hold secondary education.

Analyzing all of this again indicates that there is no clear managerial view for the conducting of the professional social activity. Until revoking the educational requirement for practicing the social work occupation (social activities) an impression was created in those employed in that field that there is a strive the social worker to get positioned among other experts as an expert with professional qualities as outlines are his specific fields of activity and clearly defined is his purpose during work. This was reported as legitimation of the "social work" occupation, creating some certainty in those employed and as a step in the direction of intuitional strengthening of the social assistance system. The reoccupation of the educational requirement contradicts with the logic of the reform and the accepted differentiated approach in social assistance and voids the existence of specialized education in social activities.

In the beginning of 2003 in the social assistance system employer are about 15000 people as 6184 of them are in social services facilities and 5632 in Social Assistance Directorates (Council of Ministers.2002), 21\% are employed in municipal activities in the field of social services. The personnel in the system were decreased with about $16 \%$ as oppose to 1990 (M. of Labor and S. Policy 2003). In various structures employed are about 5200 social workers as they are $78 \%$ of the composition of Social Assistance Directorates and $9 \%$ of the panel of social institutions for rendering social services. The assurance of population with social assistance system personnel for the year 1990 is 2.1 employed per 1000 people of population and for 20031.9 employer per 1000 people of population.

In the last 14 years the norms for serving the population has been altered several times. In 19901 social worker services about 33000 people of territorial population, 1991- 1 social worker per every 7000-8000 people and 1992- 3000 people (Lyubomir.1993). In 1999 Ministry of Labor and Social Policy defines normative for Municipal Social Assistance Services - 1 social worker per 2500 people of population and 2 social workers in social services facility. Currently the assurance for the population with social workers average for the country is 1 social worker per 1500 people as it varies for various municipalities.

Given are data about the assurance of the social assistance system in Great Britain (England, Scotland) with social workers. The attention is focused on the United Kingdom with review of observed preferences towards the British model when modernizing the social assistance system in Bulgaria.

\section{GREAT BRITAIN}

As per data of those employed in the public sector (DoH.2013), the number of those employed in the social assistance decreases for the period 2002-2012 as the number of social workers increases from 26509 in 2002 to 35200 in 2012. In 2012 only in England the employed ones are 27230 as 55\% of them work parttime. Of them $16 \%$ are men. Social workers are $11 \%$ of the personnel. Of them only $1.86 \%$ are situated in daycare centers, $7.4 \%$ in hospital facilities. Most of them work in municipal social services. According to the groups of clients: $46 \%$ of social workers work with children, $22 \%$ with elderly, $18 \%$ people with disabilities, $1 \%$ with people with specific problems (HIV, alcohol, drugs) and $13 \%$ are not oriented towards certain group of clients. The assurance with personnel is 5.5 employed per 1000 people of population, averagely for the country 1 social worker services about 1615 people. The assurance with social workers for work which

\footnotetext{
*or England and Wales jointly
} 
children is 1 social worker per 800 children under the age of 18 .

\section{SCOTLAND}

According to data for 2012 in social services in Scotland 47446 people are employed as 25598 people are working part-time (54\%). The number of employed decreases with $7 \%$ in 2012 as oppose to 2006 , mostly at the expense of the part-time work $\left(91 \%\right.$ of the released are part-time workers) ${ }^{*}$. The dynamics of personnel within 2006-2012 indicates that from 2006 to 2012 personnel in social services decreases with about $4 \%$ per year as for the first two years the decrease is mostly at the expense of those employed full-time and in the next year as result of restricting the part-time labor. For the six-year period being reviewed noticed is permanent tendency most of half the personnel in social service facilities to be employed part-time.

For the period 2006-2012 the assurance with personnel changes as for 2006 it is 7.5 employed per 1000 people of population and the lowest is reached in 2010-6.6 per 1000, in 2012 it is 7.1 per 1000 of population. The assurance as per groups of clients is respectively: services for children 5.1 people personnel per 1000 people of population below working age, for services for adults- 5.5 service 1000 of population over 18 years of age, for criminals- 0.4 people per 1000 people of population in working age, services for more than one risk group- 0.6 per 1000 of population.

Over $1 / 4$ of those employed carry out homecare, $1 / 4$ are in social services, about $17 \%$ work with adults (elderly, disabled, people with mental retardation, metal diseases, people with specific problems- drug addicts, alcoholism, HIV) in stationary facilities and $10 \%$ in daytime care centers. Most of the personnel (64\%) is engaged with rendering services for the elderly, $16 \%$ - children, $4 \%$-criminals, $8 \%$ - more than one risk group, $8 \%$ of those employed practice managerial functions. The gender structure of personnel is strongly feminized $-85 \%$ of employed are female. Most females are engaged with work for the elderly where females are over $90 \%$ of personnel, lowest is the relative share of females $(59 \%)$ servicing criminals.

Social workers are 4252 people or $9 \%$ of personnel in the system ${ }^{\dagger}$. They work at municipal social services. They make up $38 \%$ of the employed in the services. Social workers are $56 \%$ of personnel in children sectors, $36 \%$ in adults, $46 \%$ of criminals and $17 \%$ employed are working with more than one risk group. In the daycare homes and stationary facilities there are no social workers. Despite that in recent 10 years the number of social workers increases there is still working places as for the 2012 they are respectively $11 \%$.

Social workers, in relation to all personnel of the social assistance system as per main groups of clients are $30 \%$ of personnel working with children, $4 \%$ - with adults, $45 \%$ of personnel engaged in services for criminals and $16 \%$ of personnel working with more than one risk group. In total may say that one social worker serves 1246 people on average for the country as assurance with social workers working with children is 1 social worker per 580 inhabitants under 18 years.

In qualification terms only $9.6 \%$ of workers in the education system are in major "social work”, respectively occupational qualification - social worker, $10.4 \%$ with qualifications acquired through education - qualification courses within the system. Most of the personnel has no training in social work and social care. Education in „social work" hold $94 \%$ of social workers, $66 \%$ of managers at different levels, $22 \%$ of personnel within the group "other qualified personnel” - organizers of care, special rights employees, occupational therapists, supervisors of criminals.

Data about Great Britain and Scotland show that the number of personnel in various districts depends on local social assistance needs (welfare payments and social services). Influenced by factors such as deprivation and urbanization, degree of socio - economic development, degree of development of social services in the region, degree of interaction of local authorities with other organizations and neighboring districts in rendering the services.

The qualification level of employed ones is not very high. Its improvement is aimed in direction of:

- Recruitment and prequalification of personnel. Most of the personnel has no qualification in the field of social work and social care. Observed is permanent tendency for the increase of the number of social workers. Despite, annually reported are free working places. For their holing attracted are experts from other professional divisions as teachers and nurses.

- Improving the training and occupational qualification of social workers. Introduced is new academic

\footnotetext{
"Personnel of Scottish Local Authority Social Work Services, Statistical Bulletin SWK/S/2013/24, Scottish Executive Statistical Services

${ }^{\dagger}$ for 2013 they are4384 people and for 2014 - 4511 Personnel of Scottish Local Authority Social Work Services, Scottish Executive Statistical Services, 2014
} 
degree in social work with duration of training 3 years. It starts in Great Britain (2003), Wels, Scotland and Northern Ireland (2004). The expectations are for overcoming the crisis in social work education as every country provides training complying with the needs of the population and the requirements of its social structures. Reported is that in recent years there is outflow of social work education. Less young people choose the occupation of the social worker as their work realization. In order to increase the probability in this occupation included to be appropriate candidates, measures are adopted for improvement of the practical training and financial training for social work students.

\section{- Deregulation and decentralization in education and training in social work.}

- Reporting regional differences in the field of social work as enhanced is the role of the newlyestablished Social Service Councils in every country. They replace in 2001 the Central Council for Education and Training in Social Work (CCETSW) which was the national regulatory authority in the field of training and qualification in social work. This way every country receives the right to develop and apply own strategy in human resources management.

- Increase of personnel's qualification in municipal social services (the so-called "front line personnel") for effective work, improvement of the quality of service, not allowing discrimination or violation of citizens' rights.

- Rationalization of the number of composition of personnel through: using flexible forms of employment in the field of social care (part-time work, sharing position, temporary employment contract work)

- Creating work places appropriate for people without any qualification or with low qualification in the field of social services. Those employed serve clients directly by providing them personal care, daily living activities, social networking and social workers perform duties in managing the process of providing care. This feature of social services defines the relatively low share of the social workers from the total number of personnel working with the elderly and disabled people.

High qualification requirements to personnel at all levels engaged with services with children. Social workers consist of significant part of personnel working with children. They perform not only control but also methodic functions but they immediately take part in service of clients.

- Using the opportunities of continuous occupational training ${ }^{\star}$ for improvement of qualification level of personnel with review of higher qualify of social activities being performed at national and regional level developed is training policy which includes issues on introducing new procedures, services, work methods, structural and/or organizational changes. Present is strategy for continuous occupational training and its security with material and financial resources. This way for example in Scotland every regional social activity directorate has a plan/ program for continuous occupational training, supported with a certain budget ${ }^{\dagger}$. There is own training center. It conducts occupational training of non-qualified personnel in the field of social care in 6 degree, past-graduation qualification together with higher institutes in 2 degrees for certified social workers and planned training of various categories of personnel in the social assistance system as per specific practical issues as mostly short-term courses. The activity of the training centers is methodically supported by the Council of Social Services in Scotland.

The British experience suggests that the assurance of the population with personnel performing professional social work in our country should take into account regional differences, institutional and group-specific community peculiarities. Given the limited financial resources necessary is to effectively use available personnel to increase customer satisfaction with the quality of service. Basic resources are improving education and qualification level of employees and improving the organization of labor (labor organization is a separate issue that requires to be subject to other independent studies and will not be considered in details herein).

The analysis of the measures so far taken by the Social Assistance Directorate in terms of personnel indicates adherence to a strategy based on the use of all the possibilities for better and more efficient use of employees as the effect is flexible number at reduced full-time personnel:

- Update of the work schedule and job descriptions.

- Delegating certain activities of assistance-experts (for example socio-cultural consultants), hired as per

"As "continuous training" understood is events or activities for training aiming to develop or perfect the existing knowledge or acquiring of new qualifications, entirely or partially funded by the organization for its employees with are working with employment contract (NSSI).

${ }^{\dagger}$ for 2012 granted are additional 3.5 million pounds for training of personnel from the municipal social services 
national program „social assistance to assuring employment”. The disclosing and funding of work places is at project principle.

- Attestation and employee training. Since 2003 in the territorial divisions of the Social Assistance Agency annually held is attestation of employees. Adopted are five levels of overall evaluation of performance as first degree is highest. (Ordinance on conditions and procedures for the appraisal of civil servants Official Gazette issue No 54/2002). There is no such practice in specialized institutions and social care centers in the community. They actively use informal forms of continuing occupational training (courses, demonstration of good practice) as they are mostly aimed at personnel working with children and mentally disabled people. In view of the limited financial resources accepted is practice to organize courses for managerial employees of large municipalities through which instructions, briefings and other events provided is information to subordinates. An active role plays the "Social Assistance" Regional Directorates which within the methodical function use some informal forms of continuing occupational training to maintain awareness and increase training and qualifications of employees.

- Improving labor organization in Social Assistance Directorate through using regional, team and rotational principle of work, applying flexible weekly schedules, reporting the loading of social workers and specialization in their employment duties in accordance with the client in the respective municipality. Territorial peculiarities find reflection in the permitted differences in the organizational structure regarding the number of receptions for citizens according to fields of activity and gains: cash support, family allowance for child protection and service of disabled people. Rotation of social workers as per regions contributes to the establishing and remedy of omissions and violations.

\section{CONCLUSION}

As previously noted social work is a new occupation in Bulgarian professional life. Interest is any study of professional social work. From a research perspective, prominently placed is the first social representative study among social workers in Bulgaria. It outlines the main problems in their work lives. It was conducted by the Social Analyses Agency at Ministry of Labor and Social Policy in 1999 (L.D.2007). The data reveal that the occupation of "social work" is considered controversial by those who exercise it. Social workers say it is attractive because it is associated with various contacts, but at the same time intense, risky and thankless. Most social workers like their profession but have serious reservations about their specific job. The study identified three main groups of factors that influence job satisfaction of social workers and affect their professional confidence (2002a-c,2003a-e,T.2004,2012a-b,2014a-d,2015a-d,2016a-b).

The first group of factors is related to the nature and content of work. The type of work relatively most commonly leads to satisfaction among social workers. According to the results, $38 \%$ of them are completely satisfied, $54 \%$ somewhat satisfied, $3 \%$ are not satisfied with their work as social workers. Almost $90 \%$ of social workers identified as the most attractive feature of their work the opportunity to help people. This feature is a major source of satisfaction and pressure depending on whether it exists, and to what extent. Tension in working as social workers is due to: the inability to help all those in need (59\%); irregular provision of funds for repayment of the aid (54\%); regulatory shortcomings due to discrepancies with actual practice; limited power of social worker; lack of sufficient funds. According to a third of social workers discrepancy between desire and opportunities between needs and eligibility for benefits between declared and actual needs of citizens leads to conflicts, resulting in dissatisfaction and aggressiveness of their clients.

The second group of factors is associated with the conditions, organization and remuneration. Social workers give comparatively most positive assessments of colleague climate in social services (58\%). Only $28 \%$ said they work in completely satisfactory labor organization, and $16 \%$ are satisfied with the working conditions. For the most part, social workers are dissatisfied with various shortcomings of their working environment (lack of equipment and supplies for work (48\%); large volume of work (32\%), lack of unified information system, difficulties when conducting social polls, heavy contingent).

The most massive and strongest dissatisfaction among social workers is caused by the payment of their labor (69\%). Some of the interviewed said they would leave without hesitation if they find a better paid job. Frustration causes also the limited opportunities. Overall, a big part of the social workers are not satisfied with the conditions, organization and remuneration. The profession of social worker in their eyes has a low social status and they remain not consistently valued for their efforts.

The third group of factors reflects the common image of the profession and impacts on the professional selfconfidence of social workers. According to the research every tenth of them shares that society does not recognize or value their labor. Recommendations are made for increase of the public image of the occupation and improvement of the social workers' qualification. 
Research shows that most of the social workers here like their work but they have serious requirements for improvement of the work conditions and organization, adequate payment, better professional development opportunities. This conclusion is confirmed by a research concluded among social workers in district of Ruse in 2015. Data indicates that $50 \%$ of those interviewed are satisfied with their work, $22 \%$ are disappointed because their work did not meet their expectations and only $25 \%$ would not leave the social assistance system if opportunity in another field is granted to them.

Studies have shown problems in the professional realization of social workers. The data shows that they have the experience but lack the skills for social work. There is no effective system of qualification. Management of human resources in the social assistance system does not comply with the requirements and motivation of experts capable of individual work with clients in different groups. There is a contradiction between attempts to adopt Western models and implement social activities and actual practice that offers opportunities to retain skilled personnel.

Based on the status and prospects of social assistance, the following prerequisites an objective nature to enhance the skill level of employees in the system in the direction of increasing the share of social activities experts (social workers with a university degree in social activities):

- Legislative preconditions. They are associated with a change of social assistance policy. The main objectives of which are reflected in existing national strategies and programs to tackle poverty, equal opportunities for disabled people, integration of minorities in Bulgaria. Adopted are series of laws and regulations that put contemporary context of social assistance in the country (Social Assistance Act, Child Protection Act, Family Allowances Act, Protection, Rehabilitation and Social Integration of the Disabled Act). They legitimize social work as practice. They establish normative preconditions for changes in the work of social workers related to responsibility and complexity of their work duties.

- Financial preconditions. They are associated with changes in the funding of social assistance. Taking a clear financial commitment from the state for actions that are government's responsibility. Introduction of social services charges. Involvement of NGOs and municipalities in providing services. Defining their responsibilities. Identifying opportunities to fund their services on a project basis. Developing a mechanism for financial support of non-profit organizations providing social services. All these changes are directed towards retaining costs for social assistance and reaching financial stability. The analysis shows that satisfying the needs of the population on welfare and social services is sought within the existing personnel at the expense of its intensive use.

- Managerial preconditions. They are related to improvement of the administrative capacity of the social assistance system and harmonization of its structures with European legislation. Perfecting the coordination between various structural levels. Development of national standards for social care and qualification of those employed in the system.

Improvement of qualification characteristics and assurance of the system with experts in social activities imposes development of adequate strategy and policy for human resources management, in compliance with the objectives of social assistance as sought are opportunities with relation to:

- Analysis and design of positions in various structures of the system. Creating work structure allowing execution of the complete volume of activities, complying with their targets.

- Recruitment and selection of personnel. Endeavors to recruit personnel that will best deal with labor problems of respective positions, taking into account on one hand the impact of factors characterizing the state of the local labor market (unemployment, characteristics of supply and demand of work force, wages and social benefits) on the other hand - factors related to the size and financial status of the social institution, policy adopted on personnel and its selection, specifics of positions. The requirements for candidates to work in the social welfare system are not particularly high and correspond with low pay and not particularly good working conditions.

- Training, qualification, prequalification and career growth. Created are opportunities foperfecting the performance within the respective positions and structural units. Gaining knowledge, skills and attitude of those employed in the system in connection to the task being performed and the clients. Strengthening of the existing Human Resources Development and Regional Initiatives Center at Ministry of Labor and Social Policy (2007) as well as cooperation between the Ministry of Labor and Social Policy and higher institutes preparing experts for the social assistance system. The analysis of the condition and perspectives before the social assistance in Bulgaria outline the need of training in social work as the social workers themselves indicate that "necessary are more competent experts with ability to work with people" (L.D.2007).

- Evaluation of performance. Development of strategy and policy for the evaluation of the personnel. It is 
the foundation for internal regulations for the evaluation of performance. Its implementation would help reveal opportunities for improving the performance, establishing the extent to which employees meet the job requirements, giving the personnel the potential for development in the profession and career and more. The evaluation of performance reveals existing reserves and creates conditions for more effective engagement of personnel. In our country there is no tradition in this area. In view of the higher demands towards personnel in the social assistance system it is desirable to monitor their performance in terms of knowledge of the matter, understanding of job tasks and their functions, using the expertise, teamwork as thus determined will be the specific needs of training or prequalification of employees.

On the other hand the efficient use of personnel is related to:

- Maintaining a level of work salary providing satisfactory life standard of the workers;

- Attracting them when solving issues affecting their interests;

- Perfecting the motivational environment as taken into consideration are not only remuneration, praises, sanctions, promotions but also providing freedom of action when performing assigned tasks, opportunity for development and career growth, recognizing achievements;

- Improvement of personnel's characteristics (precise definition of the requirements for holding the position of the "social worker", assigning candidates with specialized training in the field of social work, maintaining awareness and perfecting the occupational qualification in compliance with the changing requirements of the position being held);

- Improvement of the labor conditions and organizations (introducing contemporary information technologies, improving the work conditions in compliance with the requirements for healthy and safe work conditions, efficient use of working hours);

- Using flexible strategies (employment modes allowing change of the number of personnel as part-time work (suggests presence of sufficiently accurate reports about the volume of work that is proposed to be done part-time as allows hiring personnel for such duration of the work day that is sufficient for the execution of the duties characterizing the respective position. This form is used with social activities performed as per National Program „From Social Assistance to Employment”), temporary work agreement (gives opportunity to hire personnel for such term for which existing is necessity in order to bind the employment to the performance, for example - jurist at the child protection departments in some municipalities), flexible group(used in team practice, social workers of the respective team are interchangeable and complete one another in every work situation as result of their wide-specter training); flexible work (introducing flexible functions and positions which allows extending the scope of the duties, for example in various Social Assistance Directorates announcing competitions for jurists is withheld and their duties are performed by the legal adviser of the Social Assistance Regional Directorate).

Comments of effective use of social workers' labor are possible only if taken into consideration is their social work. It suggests wide-profile training, high qualification and motivation for comprehensive realization (the training and prequalification model are reviewed in chapter third). This makes social workers able to adapt to all changes in technology, organization and structure of rendered social services and supplementary activities. Assumed may be that the efficient use of their potential is related to the increase of their fruitfulness of labor (enrichment of employment function), reduction of uniformity and monotony, enhance of mental tension, possibility for versatile application.

The reform in the social assistance system and the dynamic demands of population precondition the necessity of this type of experts with complex training, allowing them to undertake greater responsibilities and perform more complex work tasks when performing social activities in the conditions of restricted financial resources and their rational use.

\section{REFERENCE LIST}

Turner, 1986; Howe, 1987; Payne, 1991 (T.1986).

Yana Merdzhanova, Boncho Gospodinov (Y.2003), For the Professional Profile of Social Worker, magazine

"National program „From Social Assistance to Employment”, type of social activity with hourly measure (Appendix No 1), Weekly schedule for one hired employee (Appendix No 2), measurer of social service activities (Appendix No 3) 
"Strategies of Educational and Scientific Policy”, issue No 1, 2003.

Zastrow, C.H. The Practice of Social Work, Brooks/Cole Publishing Co (Z.1999a)., Passific Grove, 1999.

Morales, A., B. W. Sheafor, Social Work (M.1999). A Profession of Many Faces, Allyn and Bacon, Boston, 1999.

Dave Sugdenand Co (D.2003)., Manual for Conducting Practical Training in Social Work, V. T. 2003.

Pavalko, R. M (P.1971)., Sociology of occupation and professions, Itasca, ILL, 1971, p.17-27.

Economics Club (E.2010), Issues of the Bulgarian Children's Welfare, 2010.

Lyubomir Yonkov (Lyubomir.1993), Up-to-date Issues of the Social Care System, 1993.

Evgeniya Spasova (E.1996), Social Integration of Independent Population Groups, Plenary Report of International Conference, 1996.

Pursuant to resolution № 612/12.09.2002 by the Council of Ministers. According to data by the Structural Rules of Social 11. Assistance Service (Official Gazette issue No 15 / 2003, amended Official Gazette issue NO 63/2003). The total number of personnel is 5790 people as for Social Assistance Directorates it is 5323 people (Council of Ministers.2002).

As per data by Ministry of Labor and Social Policy, 2003 (M. of Labor and S. Policy 2003).

DoH, Personal Social Services Personnel of Social Services Departments, London, Department of Health, 2013 (DoH.2013).

Liliya Dimova, Social workers for the irwork, Bulletin No 2, May 2007, Ministry of Labor and Social Policy (L.D.2007).

Терзиев, В., И. Аврамова (2002а), Социалната политика в контекста на Европейската интеграция и реализиране на изследване на възможностите за въвеждане на технологията „План за действие”, Сборник с доклади от IV ${ }^{\text {-та }}$ Национална научно-практическа конференция „Службите по заетостта и новите предизвикателства за реализиране на активната политика на пазара на труда", 14-15 май 2002г., Русе, стр.13-21.

Терзиев, В. (2002b), Национална програма „От социални помощи към осигуряване на заетост”, „Труд и право”, бр.11, София, ноември 2002г. стр.38-41.

Терзиев, В.(2002c), Общините и социалното подпомагане, Информационен бюлетин „Реформата в местното самоуправление“, бр.12, Фондация зареформа в местното самоуправление, София, 2002г.

Коцева М., В. Терзиев, 3. Андреева (2003а), Проблеми на оценката на активните политики на пазара на труда, Пета национална конференция „Службите по заетостта и Европейския пазар на труда”, Русенски университет „Ангел Кънчев”, МТСП, АЗ, Русе, 29-30 май 2003г., стр.9-13.

Терзиев, В., А. Делибашева (2003b), Социална подкрепа и партньрство в сферата на професионалното ориентиране за младежи и възрастни, Първа научно-практическа коноеренция с международно участие „Мрежи за професионално ориентиране за младежи и възрастни”, Икономически университет, Варна, 4-5 юни 2003г., стр.3-12.

Наньова, Ц., В. Терзиев (2003с), Осигуряване на заетост на лица в неравностойно положение. Финансово стимулиране на работодатели за разкриване на нови работни места. Адаптивност имобилност на работната сила, Юбилейна международна конференция „Трудът и неговата защита презXXI век", Университет за национално и световно стопанство, София, 29 май 2003r.ISBN 954-494-539-3, стр.288-300.

Терзиев, В. (2003d), Национална програма „От социални помощи към осигуряване на заетост”, Информационен бюлетин по труда, кн.2, София, 2003, стр.32.

Терзиев, В. (2003е), Новият социален модел, като ефрективна възможност за реализиране на активната политика на пазара на труда в България, Национална научно-практическа конференция „Гъвкавата заетост и проблеми на нейната регулация”, Пловдивски университет „Паисий Хилендарски”, Пловдив, 4 юли 2003г. ISBN954-561-146-4, стр.56-71.

Терзиев, В., Ю. Младенов, М. Стойчев (Т.2004), Изследване възможностите за трудовата реинтеграция на продължително безработни лица на пазара на труда чрез програма за заетост, УНИТЕХ'04, Габрово, 18-19 ноември 2004г. Том III. ISBN 954-683-305-3, стр.62-66. 
Терзиев, В. (Т.2005), Общ анализ на въздействието на програмата „От социални помощи към осигуряване на заетост" на националния трудов пазар, УНИТЕХ'05, Габрово, 24-25 ноември 2005г. Том III. ISBN954-683-326, стр.75-80.

Терзиев, В., Ю. Младенов (2012a), Активна социална програма и нейното стратегическо преимущество, Научни трудове на Русенски университет „Ангел Кънчев”, Том 51, серия 5.1., Русе, 2012г. ISSN 1311-3321, стр.9-14.

Терзиев, В. (2012b), Критерии и показатели за социална ефективност, Международна научна конференция, Сборник доклади, том III, Габрово, УНИТЕX 16-17 ноември 2012г. ISSN 1313-230X, стр.231-240.

Димитрова, С., В. Терзиев (2014а), Предложения в области социального капитала, партнерства и сети. Развитие социальной экономики. Поддержка социальной инновации, Международная научно-практическая конференция „Экономические науки: теоретический и практический взгляд”, 1 октября 2014, Уфра, Россия. ISBN978-5-906769-05-3, pp.37-42.

Терзиев, В., С. Димитрова (2014b), Определяне на критерии и показатели за социална ефективност, Юбилейна научна конференция 2014 „100 годиниавиационно образование в България”, Национален военен университет „Васил Левски”, 9-10 октомври 2014г., гр.Долна Митрополия. ISBN 978-954-713-216-8, стр.195-209.

Терзиев, В., С. Димитрова (2014c), Ролята на социалната политика в икономическото развитие, Юбилейна научна конфреренция 2014 „100 годиниавиационно образование в България", Национален военен университет „Васил Левски”, 9-10 октомври 2014г., гр.Долна Митрополия. ISBN 978-954-713-216-8, стр.228-239.

Терзиев, В. (2014d), Социалното програмиране в системата на социалните категории, VII Международная научная конференция „Инновации в технологиях и образовании” (КузГТУ), Белово, Россия, 2014. Сборник статей часть 2. ISBN978-5-89070-974-5, pp.289-298.

Терзиев, В., Е. Арабска (2015a), Социалното програмиране в контекста на насърчаване на социалната активност. Юбилейна международна научна конференция „Социалните науки и развитието на обществото - теоретични и практически измерения”, Свищов, 30-31 октомври 2015 г. ISBN 978-954-23-1093-8, стр.228-233.

Терзиев, В., Е. Арабска (2015b), Активните трансформации в политиките за функциониращ пазар на труда и за заетост. Научна конференция с международно участие „Иновации в образованието“, 25-27 септември2015г. ШУ „Епископ Константин Преславски“. Годишник на ШУ „Еп. Константин Преславски“, т.XIXD Педагогически фракултет, ISSN 1314-6769, Научни трудове от конференция, стр.96-104.

Терзиев, В., Е. Арабска (2015c), Изграждането на функциониращ пазар на труда в периода на преход на българската икономика. Научна конференция с международно участие „Иновации в образованието“, 25-27 септември 2015г. ШУ „Епископ Константин Преславски“. Годишник на ШУ „Епископ Константин Преславски“, т. XIXD Педагогически факултет, ISSN 1314-6769, Научни трудове от конференция, стр.82-95.

Терзиев, В., Е. Арабска (2015d), Мониторинг на активните политики на пазара натруда в България, Първа научно-практическа конференция с международно участие „Социална работа, мениджмънт и социално развитие: съвременни предизвикателства, перспективи и иновативни практики 2015", 1-2 октомври 2015, ТУ-Варна. ISBN 978-954-20-0750-0, стр.32-39.

Терзиев, В. (2016а), Приложение на социалното програмиране в регулирането на социалното развитие: ефективни социални политики чрез насърчаване на социалната активност на човешкия ресурс. Годишник/CА „Д. А. Ценов”, ISSN 0861-8054, Том CXIX, Свищов 2016, стр.7-91.

Терзиев, В., Е. Арабска (2016b), Основни профили на безработните лица в България. Четиринадесета младежка научно-практическа конференция, 19-20 април 2016г. Федерация на научнотехническите съюзи, София. Сборник доклади, ISSN 1314-8931, стр.198-205.

Терзиев, В., Е. Арабска (2016с), Динамика в уязвимите групи на пазарана труда в България. Четиринадесета младежка научно-практическа конференция, 19-20 април 2016г. Федерация на научно-техническитесъюзи, София. Сборник доклади, ISSN 1314-8931, стр.206-217.

Терзиев, В., П. Димитрова (2014е), Развитие системы социальной поддержки в Болгарии, Сборник статей Международной научно-практической конференции „Актуальные проблемы современной 
науки", Аэтерна (Уфра) 2014, ISBN: 978-5-906769-47-3, стр.281-293.

Терзиев, В., П. Димитрова (2014f), Развитие структуры системы социальной поддержки Болгарии, Сборник статей Международной научно-практической конференции „Актуальные проблемы современной науки", Аэтерна (Уфа) 2014, ISBN: 978-5-906769-47-3, стр.294-307.

Terziev, V. (2012c), Social technology as a method for management of the social processes, International Conference "Trends in economics and management for the $21^{\text {st }}$ century" (2012), Brno, Czech Republic, ISBN978-80-214-4581-9, pp.79-80.

Terziev, V. (2012d), The active model of a social programme and its strategic advantage, International Conference "Trends in economics and management for the $21^{\text {st }}$ century" (2012), Brno, Czech Republic. ISBN 978-80-214-4581-9, pp.77-78.

Terziev, V. (2013a), Social technology as a method for management of the social processes, International Conference on Business and Economy (ICBE) Interdisciplinary studies on a new economy, 5-7 June, Constanta, Romania, 2013. pp.258-265.

Terziev, V. (2013b), The active model of a social programme and its strategic advantage, $12^{\text {th }}$ International Scientific Conference: Management Horizons in Changing Economic Environment\& Visions and Challenges, Kaunas, Lithuania on September 26-28, 2013, ISSN2029-8072, pp.917-932.

Terziev, V. (2015e), S. Dimitrova, E. Arabska, Linking active social policies to education and qualification problems on the labor market. Humanitarian approaches to the Periodic Law // Humanities and Social Sciences in Europe: Achievements and Perspectives. Proceedings of the 6th International symposium. "East West” Association for Advanced Studies and Higher Education. Vienna. 2015. ISBN-13 978-3903063-01-3, ISBN-10 3-903063-01-0, pp.277-289.

Terziev, V. (2015f), S. Dimitrova, E. Arabska, „From social support to employment”: considering target groups' needs in actice social policies. Актуальные проблемы социально-экономических исследований: сборник материалов. VIII Международная научно-практическая конференция, (г.Махачкала, 24 января, 2015г.) Махачкала: ООО „Апробация”, 2015. ISBN 978-5-906616-72-2, pp.10-21.

Terziev, V. (2015g), Social programming in the system of sociological categories concerning market economy and labor market development in transition economy, Конференция „Культура. Духовность. Общество”, ЦРНС, Новосибирск, Россия, 2015, ISBN 978-5-00068-278-4, pp.100-123.

Terziev, V.(2015h), S. Dimitrova, Ekaterina Arabska, Social activity of human resources - a basis for effective social policy (Социалната активност на човешкия ресурс - основа за ефективна социална политика), Fifth international scientific and applicative conference KNOWLEDGE - WHO AND WHAT, 21-25 May 2015, Bansko, Bulgaria, Journal of Process Management (JPMNT) - New Technologies, International, The International Scientific Conference „KNOWLEDGE - WHO AND WHAT”(held in Bansko, 21-25 May 2015), Special Edition, Volume 9, May 2015, ISSN 2334-7449, pp.241-246.

Terziev, V. (2015i), E. Arabska, Social policy and social programming: key implications concerning development of active labor market policies and employment. Proceedings of $17^{\text {th }}$ International Academic Conference, Vienna, June 21-24, 2015, IISES, ISBN 978-80-87927-10-6, pp.499-513.

Terziev, V. (2015j), S. Dimitrova, Social activity of the human factor, Alma Mater University of Sibiu National Conference with International participation, 28 -30 of May 2015, Sibiu, Romania. Sibiu Alma Mater University Journal, Seies SC. Social sciences, Vol.8, N1, 2015, pp.41-44. 